\title{
EFFECTS OF HEAT INPUTS ON THE STRUCTURE OF Ni-BASED AMORPHOUS COMPOSITE COATINGS APPLIED WITH LASER CLADDING
}

\author{
VPLIV VNOSA TOPLOTE NA STRUKTURO KOMPOZITNE \\ PREVLEKE NA OSNOVI Ni, IZDELANE Z LASERSKIM \\ POSTOPKOM
}

\author{
Ruifeng Li1,*, Zhaohui Chen', Jiayang Gu², Yuxin Wang1, Mingfang Wu'1, \\ Yingtao Tian $^{3}$ \\ ${ }^{1}$ School of Materials Science and Engineering, Jiangsu University of Science and Technology, Zhenjiang, Jiangsu 212003, China \\ ${ }^{2}$ Marine Equipment and Technology Institute, Jiangsu University of Science and Technology, Zhenjiang, Jiangsu 212003, China \\ ${ }^{3}$ Department of Engineering, Lancaster University, Bailrigg, Lancaster, LA1 4YW, UK
}

Prejem rokopisa - received: 2018-11-09; sprejem za objavo - accepted for publication: 2019-01-30

doi: $10.17222 / \mathrm{mit} .2018 .241$

\begin{abstract}
In this paper, Ni-based amorphous composite coatings were fabricated under different heat inputs on a mild-steel substrate using laser cladding with coaxial powder feeding. The microstructure of the coating was studied using a scanning electron microscope (SEM), X-ray diffraction (XRD) and transmission electron microscope (TEM). The effects of the heat inputs on the amorphous-phase forming ability of the Ni-based alloy was investigated systematically with experimental and numerical simulation methods. The results show that there was no amorphous phase in the coating when the heat input was $131.3 \mathrm{~J} / \mathrm{mm}$. The amorphous-phase fraction increased with a decrease in the laser-cladding heat inputs from $81.3 \mathrm{~J} / \mathrm{mm}$ to $50.0 \mathrm{~J} / \mathrm{mm}$. Then a $3 \mathrm{D}$ thermal finite-element (FE) model was built to simulate the temperature field of coaxial laser cladding at different heat inputs using the element birth and death technique. Detailed 3D transient thermal analyses were performed on temperature-dependent material properties. The proposed model was validated with the experimental results. It was found that a decrease in the heat input leads to a lower high-temperature residence time and a higher cooling rate of the melted pool. Consequently, a low heat input can be considered as a necessary condition for the formation of the amorphous phase during the laser-cladding process. Keywords: laser cladding, amorphous, microstructure, heat input, simulation
\end{abstract}

Avtorji opisujejo izdelavo amorfne kompozitne prevleke na osnovi Ni s postopkom laserske obdelave z istočasnim (koaksialnim) nanosom kompozitnega prahu na malo legirano jeklo. Nastalo mikrostrukturo prevleke so analizirali s pomočjo opazovanja pod vrstičnim (SEM) in presevnim elektronskim mikroskopom (TEM) ter z rentgensko difrakcijo (XRD). Vpliv vnosa toplote na sposobnost tvorjenja amorfne mikrostrukture Ni zlitine so sistematično raziskovali z eksperimentalnimi in simulacijskimi metodami. Rezultati raziskav so pokazali, da ni prišlo do nastanka amorfne faze v prevleki, če je bil vnos toplote $131,3 \mathrm{~J} / \mathrm{mm}$. Delež amorfne faze je narasel, če so zmanjšali vnos laserske toplote (energije) z 81,3 J/mm na 50,0 J/mm. Nato so izdelali še 3D model na osnovi metode končnih elementov (FEM) za simulacijo temperaturnega polja med lasersko obdelavo koaksialnega nanosa plasti prahu pri različnih vnosih toplote z uporabo B\&D tehnik (angl.: birth and death). Izdelali so detajlno 3D termično analizo s temperaturno odvisnimi lastnostmi materialov. Veljavnost predlaganega modela so preverili z eksperimentalnimi rezultati. Ugotovili so, da lahko zmanjšanje vnosa laserske toplote vodi do zmanšanja kontaktnega časa vnosa toplote na stiku med delci in zato višje hitrosti ohlajanja lokalno nastale manjše "lužice" (bazenčka) taline. Posledično avtorji zaključujejo, da je osnovni pogoj za nastanek amorfne faze manjši vnos toplote med lasersko izdelavo izbrane prevleke.

Ključne besede: laserska obdelava (navarjanje); amorfna prevleka; mikrostruktura; vnos toplote; simulacija

\section{INTRODUCTION}

Laser cladding is a deposition welding process, in which a layer of powder is deposited on the substrate material, and the two materials are fused by metallurgical bonding through the action of a laser beam. ${ }^{1,2}$ During laser cladding, the heat-affected zone (HAZ) and melt pool are so small that a thin, metallurgical, bonded coating is produced between the cladding layer and substrate. Due to intensive heating and rapid cooling rate $\left(10^{3}-10^{6} \mathrm{~K} / \mathrm{s}\right)$, laser cladding is a feasible technique for producing amorphous coatings. ${ }^{3,4}$ Y. Y. Zhu successfully fabricated customized $\mathrm{Fe}-\mathrm{Co}-\mathrm{B}-\mathrm{Si}-\mathrm{C}-\mathrm{Nb}$ amorphous

*Corresponding author's e-mail:

li_ruifeng@just.edu.cn coatings with laser cladding. ${ }^{5}$ P. L. Zhang produced Fe-Ni-Si-B-Nb amorphous coatings with laser cladding plus laser remelting. ${ }^{6}$ G. L. Yang ${ }^{7}$ and T. M. Yue ${ }^{8}$ obtained an amorphous coating with the help of element $\mathrm{Zr}$. M. Aghasibeig applied Fe-Cr-Mn-Si-Mo-C amorphous composite coatings on AISI 1018 steel substrates using a diode laser. ${ }^{9}$ Currently, the fabrication of amorphous coatings with laser processing methods is still attracting considerable attention. ${ }^{10,11}$ An amorphous coating often exhibits a high microhardness, excellent corrosion resistance and wear resistance, and also allows extensive potential industrial applications in nuclear energy, thermal-power and chemical plants, shipping and sewagedisposal systems, etc. 
Rapid cooling is one of the main considerations for the selection of metallic-glass synthesis techniques. ${ }^{12}$ During the laser-cladding process, rapid cooling is usually achieved with a limitation of the melt to a small geometrical size and a fast removal of the laser heating source. So, it is very useful to obtain the cooling rate of the melt pool for analyzing the amorphous-formation mechanism during the laser-cladding process. However, it is very difficult to measure the temperature and dimension variations of the melt pool in real time. Currently, although several methods can be applied in a lasercladding process, none of them is universal, in particular when used with coaxial powder injection. For example, a thermocouple is only suitable for the cases of single or several fixed-point measurements of the temperature variation of the HAZ. Non-contact temperature monitoring using an infrared pyrometer is very desirable for a cladding process, but it still faces the difficulties such as the influence of reflected laser radiation and sharp variations of emissivity as well as a poor environment of practical-in-flight, molten ashes or steam. ${ }^{13}$ In addition, the measurement error of the infrared pyrometer is notable and it is also impossible to monitor the interior of the melt pool.

Recently, some numerical simulations, especially the ones using the FE method, have been proposed for calculating the temperature field and researching the evolution of the melt-pool boundary that normally affects the metallurgic bonding between the cladding material and the base material. P. Farahmand developed a three-dimensional (3D), transient, uncoupled, thermoelastic-plastic FE model to simulate a thermal process during the single- and multi-track laser cladding and the thermally induced residual stress in the laser cladding. ${ }^{14}$ Mingzhong Hao built an FE model, which was able to achieve temperature distributions for laser cladding with varying combinations of process parameters by constructing an adaptive cladding layer and moving the heat-source model using an inverse modeling approach. ${ }^{15}$ Up to now, far too little attention has been paid to the cooling rates during the laser-cladding process for the fabricating of amorphous coatings.

In this paper, the microstructures of laser-cladded Ni-based amorphous composite coatings were observed at different heat inputs. The temperature-field distribution and the thermal-cycle curve during the laser-cladding process were simulated using a $3 \mathrm{D}$ transient $\mathrm{FE}$ model. The amorphous-formation mechanisms were analyzed based on the experimental and numerical investigation results of the laser-cladding process.

\section{EXPERIMENTAL PART}

Low-carbon steel with dimensions of $150 \mathrm{~mm} \times$ $15 \mathrm{~mm} \times 10 \mathrm{~mm}$ was used as the substrate material. The $\left(\mathrm{Ni}_{0.6} \mathrm{Fe}_{0.4}\right)_{65} \mathrm{~B}_{18} \mathrm{Si}_{10} \mathrm{Nb}_{4} \mathrm{C}_{3}$ (in $x / \%$ ) alloy powder was selected as the coating material. The powder particle size varied in a range of 30-50 $\mu \mathrm{m}$. Then, nickel-based amorphous composite coatings were fabricated using the laser-cladding method with a coaxial powder feeding nozzle. Laser cladding was carried out using a $6 \mathrm{~kW}$ ytterbium-doped fiber laser (IPG Photonics) operating at $1075 \pm 5 \mathrm{~nm}$ wavelength. The beam was focused to a square spot of approximately $5 \mathrm{~mm} \times 5 \mathrm{~mm}$ at $13 \mathrm{~mm}$ beyond the nozzle, with a uniform energy distribution. A schematic diagram of the laser-cladding process is shown in Figure 1.

The optimum laser-cladding parameters were determined based on a large number of experiments to obtain a combination of favorable single-track properties including a low wetting angle, the minimum dilution ratio and high surface quality. The optimum laser-cladding parameters are given in Table 1; the heat inputs (laser power/laser scanning speed) were also calculated. To protect the melt pool from oxidation, argon shielding gas was supplied through the nozzle at $12 \mathrm{~L} / \mathrm{min}$.

Table 1: Laser-cladding parameters and their heat inputs

\begin{tabular}{|c|c|c|c|}
\hline $\begin{array}{c}\text { Laser power } \\
(\mathrm{W})\end{array}$ & $\begin{array}{c}\text { Laser scanning } \\
\text { speed }(\mathrm{mm} / \mathrm{s})\end{array}$ & $\begin{array}{c}\text { Powder feed } \\
\text { rate }(\mathrm{g} / \mathrm{min})\end{array}$ & $\begin{array}{c}\text { Heat input } \\
(\mathrm{J} / \mathrm{mm})\end{array}$ \\
\hline 2100 & 16 & 13.3 & 131.3 \\
\hline 2600 & 32 & 15.2 & 81.3 \\
\hline 3100 & 48 & 17.1 & 64.6 \\
\hline 3500 & 64 & 19.0 & 54.7 \\
\hline 4200 & 80 & 20.9 & 52.5 \\
\hline 4800 & 96 & 22.8 & 50.0 \\
\hline
\end{tabular}

Each coating was transversely cross-sectioned and etched using an aqua regia. The microstructures of the coatings were characterized with JEOL scanning electron microscopy (SEM, JSM 6460) and a transmission electron microscope (TEM, PHILIPS CM200). The sampling points of the SEM and TEM investigation were all at the middle of the coating. The phase composition of the coatings was determined with X-ray diffraction using an XRD-6000 apparatus equipped with a $\mathrm{Cu}$ radiation source.

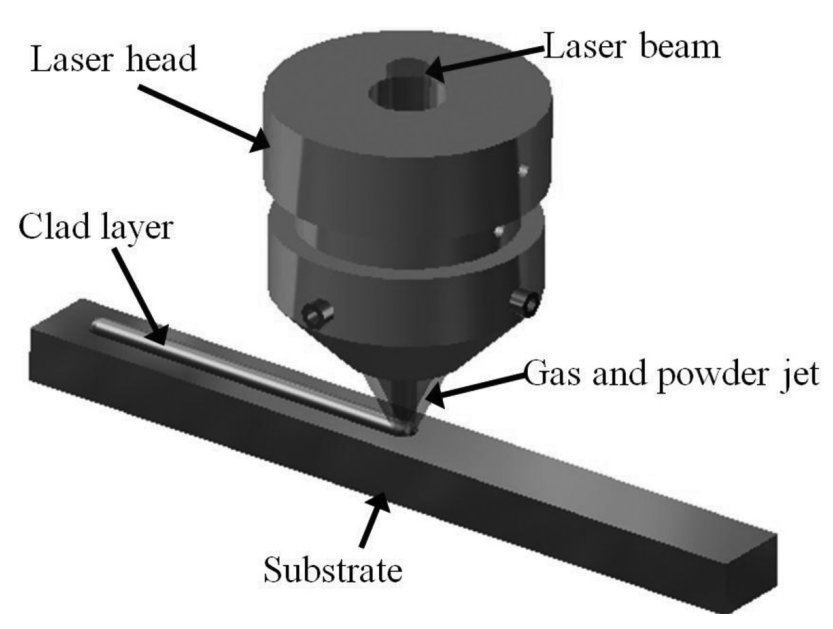

Figure 1: Schematic diagram of the laser-cladding process 


\section{RESULTS AND DISCUSSION}

Figure 2 shows the microstructure of the cladding at different heat inputs. The primary microstructure included coarse dendrites for the specimen laser cladded at a heat input of $131.3 \mathrm{~J} / \mathrm{mm}$. The SEM micrograph of the specimen corresponding to a heat input of $81.3 \mathrm{~J} / \mathrm{mm}$ also indicated the presence of dendrites. However, the dendrites became finer. Some featureless regions without crystalline characteristics were also found. Simultaneously, many particle phases were formed and the particle size was on the order of $1 \mu \mathrm{m}$. When the heat inputs were $(64.6,52.5$ and 50.0$) \mathrm{J} / \mathrm{mm}$, the featureless region became larger and larger. At the heat input of $50.0 \mathrm{~J} / \mathrm{mm}$, the cladding was predominantly formed of a featureless constituent, with some particle phases and an equiaxed dendrite phase.

Figure 3 shows a TEM image in the middle of the coating at the heat input of $50 \mathrm{~J} / \mathrm{mm}$. A selected-area electron diffraction (SAED) pattern of region $\mathrm{A}$ is also shown in Figure 3. The broad diffraction halo indicates that region $\mathrm{A}$ is an amorphous phase. The SAED pattern also confirms the formation of the amorphous phase in the coating fabricated with laser cladding.

Figure 4 shows the XRD patterns of the clad at different laser-cladding heat inputs. Figure $\mathbf{4}$ shows that when the heat input was $131.3 \mathrm{~J} / \mathrm{mm}$, the clad primarily consisted of a crystalline phase. When the heat input was lowered from $81.3 \mathrm{~J} / \mathrm{mm}$ to $50 \mathrm{~J} / \mathrm{mm}$, the XRD pattern showed that broad hole peaks appeared at $2 \theta\left(40-50^{\circ}\right)$ indicating that an amorphous phase was produced. To
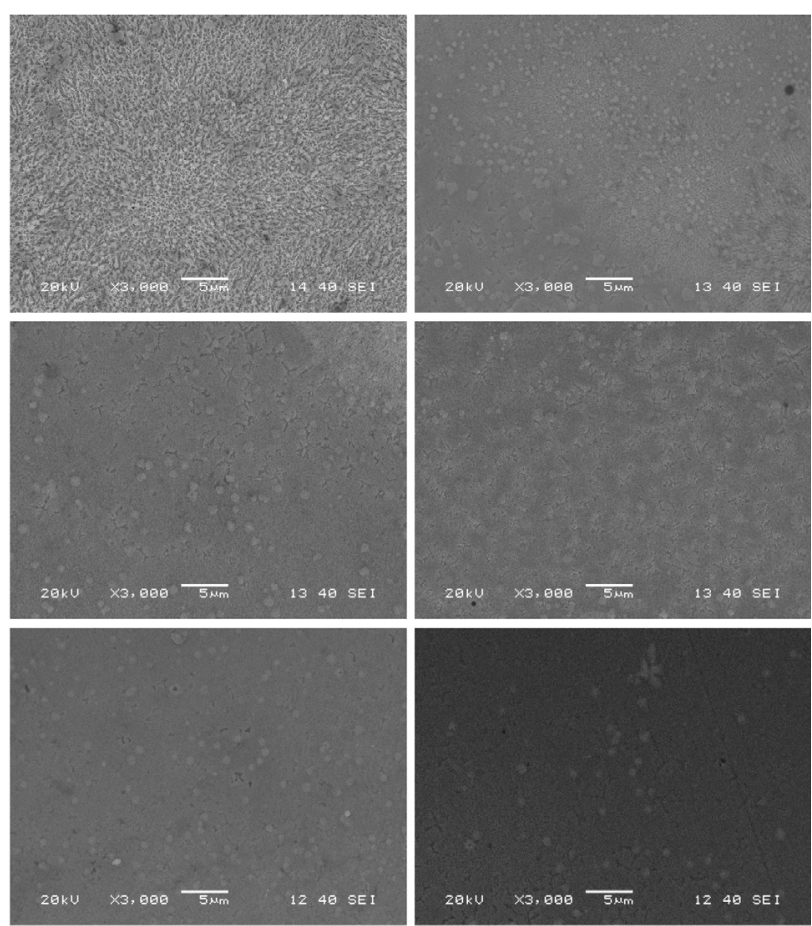

Figure 2: Effect of the heat input on the microstructure of the clad: a) $131.3 \mathrm{~J} / \mathrm{mm}$, b) $81.3 \mathrm{~J} / \mathrm{mm}$, c) $64.6 \mathrm{~J} / \mathrm{mm}$, d) $54.7 \mathrm{~J} / \mathrm{mm}$, e) $52.5 \mathrm{~J} / \mathrm{mm}$, f) $50.0 \mathrm{~J} / \mathrm{mm}$

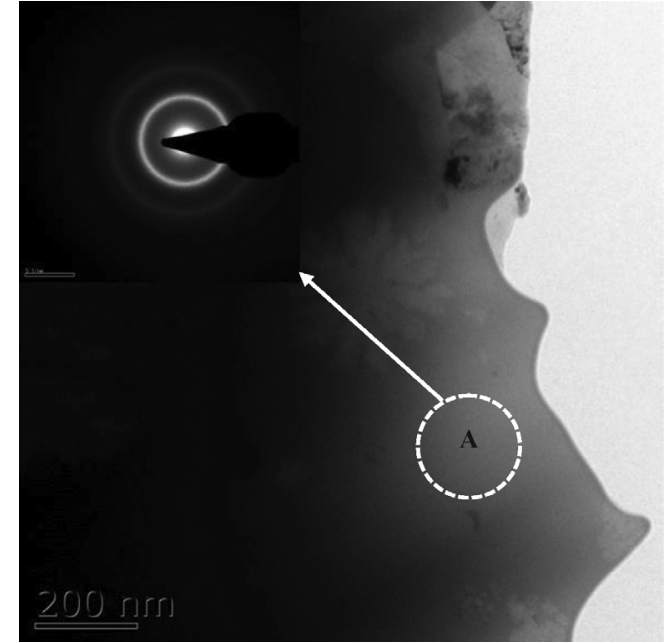

Figure 3: TEM image of the coating at the heat input of $50 \mathrm{~J} / \mathrm{mm}$

calculate the amorphous-phase volume fraction from the XRD results (Figure 4), the integrated areas of the amorphous and crystalline peaks were separated using the computer software and the $V_{\mathrm{f}}$ of the amorphous phase was calculated using the following equation:

$$
V_{\mathrm{f}}=\frac{A_{\text {amor }}}{A_{\text {amor }}+A_{\text {cryst }}}
$$

where $V_{\mathrm{f}}$ is the volume fraction of amorphous phase in the coating formed with laser cladding; $A_{\text {amor }}$ and $A_{\text {cryst }}$ are the total integrated areas corresponding to the crystalline and amorphous phases, respectively. ${ }^{16}$ The results calculated for $V_{f}$ are shown in Table 2. This table indicates that the fraction of the amorphous phase increased with a decrease in the laser-cladding heat input. A high volume fraction of $80.9 \%$ was obtained when the heat input was $50.0 \mathrm{~J} / \mathrm{mm}$. In addition, Figure 4 shows that some diffraction peaks can also be seen over the broad halo. These crystallization phases can be identified as $\gamma(\mathrm{Fe}, \mathrm{Ni}), \mathrm{Fe}_{2} \mathrm{~B}$ and $\mathrm{NbC}$. Moreover, these

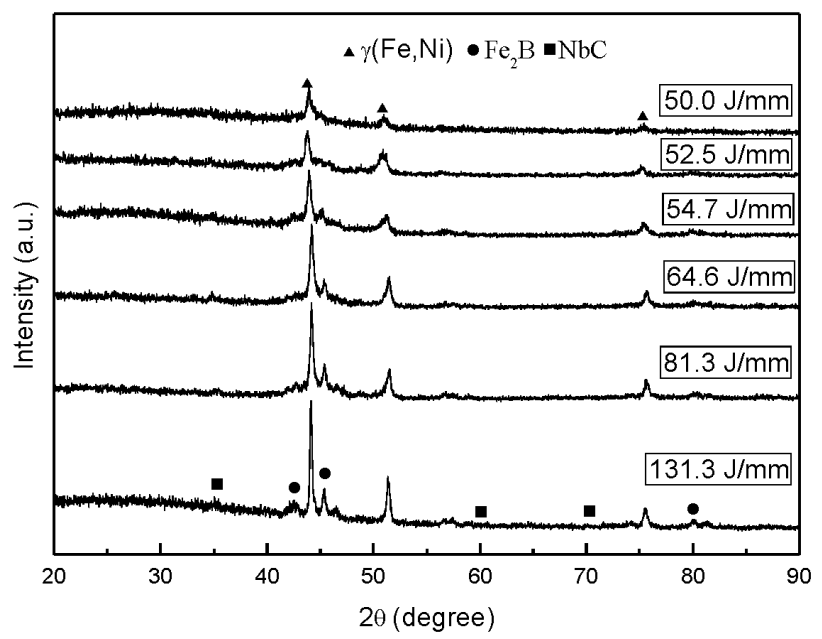

Figure 4: XRD patterns of the clad at different laser-cladding heat inputs 
diffraction peaks gradually weakened with a decrease in the heat input.

Table 2: Amorphous fraction of the clad at different laser-cladding heat inputs

\begin{tabular}{|l|c|c|c|c|c|c|}
\hline Heat input $(\mathrm{J} / \mathrm{mm})$ & 131.3 & 81.3 & 64.6 & 54.7 & 52.5 & 50.0 \\
\hline $\begin{array}{l}\text { Volume fraction of } \\
\text { amorphous phase }\end{array}$ & 0 & 35.9 & 46.9 & 66.9 & 71 & 80.9 \\
\hline
\end{tabular}

\section{FE SIMULATIONS AND ANALYSIS}

During the formation of an amorphous coating, the cooling rate is one of the most important factors. The cooling rate at different heat inputs may also change the amorphous-forming ability of a laser-cladded coating. Therefore, in this study, the temperature-field distribution and thermal-cycle curves were simulated using the FE method. Hence, it can be used to learn about the mechanism of the amorphous formation of the coating.

In order to guarantee the accuracy of the calculation and reduce the computing time, a non-uniform mesh near and along the clad was used. Figure 5 shows the FE model for the clad deposited at the heat input of $50 \mathrm{~J} / \mathrm{mm}$ and its cross-section. All the geometries of the FE models at different heat inputs are based on the crosssection profile measurements of the laser-cladded specimens. The thermal physical properties of the substrate and the cladding alloys were obtained from a reference paper. ${ }^{17}$ Heat-flow density was loaded through the form of surface heat source $F(F=\eta \times P / A)$ is the absorpti-
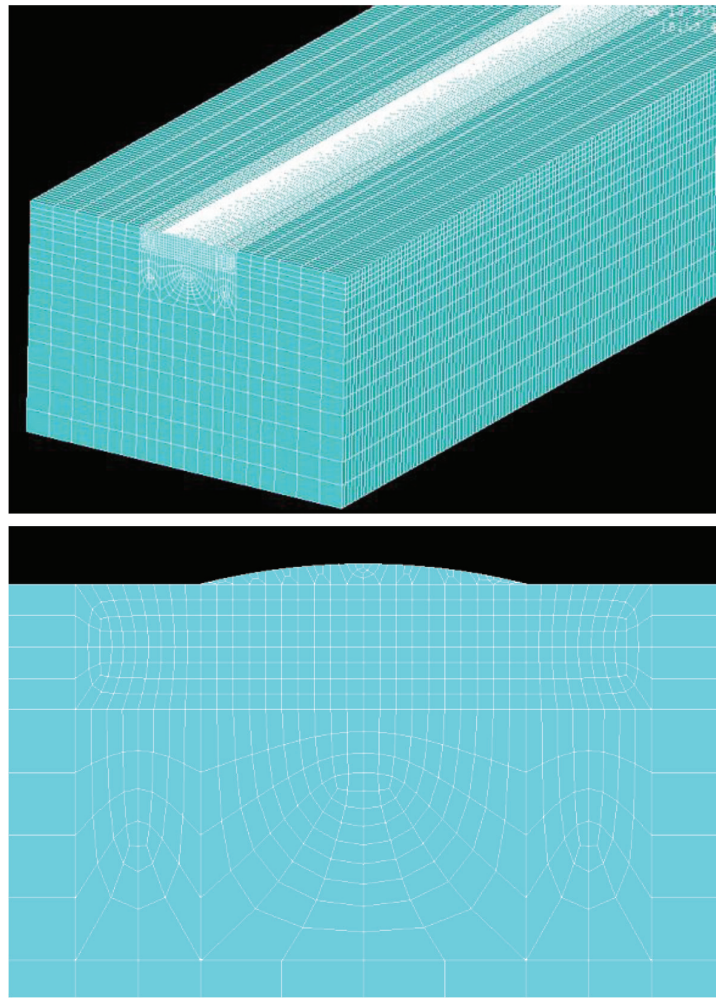

Figure 5: Partial image of: a) the FE model and b) its cross-section vity, $A$ is the laser spot area $\left(5 \times 5 \mathrm{~mm}^{2}\right), P$ is the laser power). The governing equation of the heat conduction in Cartesian coordinates is given by:

$$
\rho c \frac{\partial T}{\partial t}=k\left(\frac{\partial^{2} T}{\partial x^{2}}+\frac{\partial^{2} T}{\partial y^{2}}+\frac{\partial^{2} T}{\partial z^{2}}\right)+F
$$

where $x, y$ and $z$ are Cartesian coordinates, $k$ is the thermal conductivity, $c$ is the specific heat, $F$ is the surface heat flux, $T$ is the temperature and $t$ is the time. At the boundaries, the heat losses from the plate surfaces to the surroundings take place by means of natural convection and radiation effects. In this study, the fiber laser delivers a homogeneous energy distribution to the spot. Moreover, in order to depict the process of mass transfer due to the powder deposition on the substrate, the technique of the element birth and death is applied to the 3D thermal model. ${ }^{18,19}$

Figure 6 shows the temperature field of the clad at the heat input of $50 \mathrm{~J} / \mathrm{mm}$. As can be seen from Figure $\mathbf{6 a}$, the highest temperature appears in the surface layer of the clad. Due to the heat-conduction effect, the temperature decreases from the top to the bottom. Figure $\mathbf{6 b}$ shows a comparison of the experimental result and simulation result; the left half is a SEM photo of the crosssection, the right half shows the FE simulation results. In Figure 6b, the temperature of the region in red is higher than the melting point of the deposited material (1304 $\mathrm{K})$. It indicates that the red region was melted during the laser-cladding process. The comparison between the experimental result and temperature field indicates that

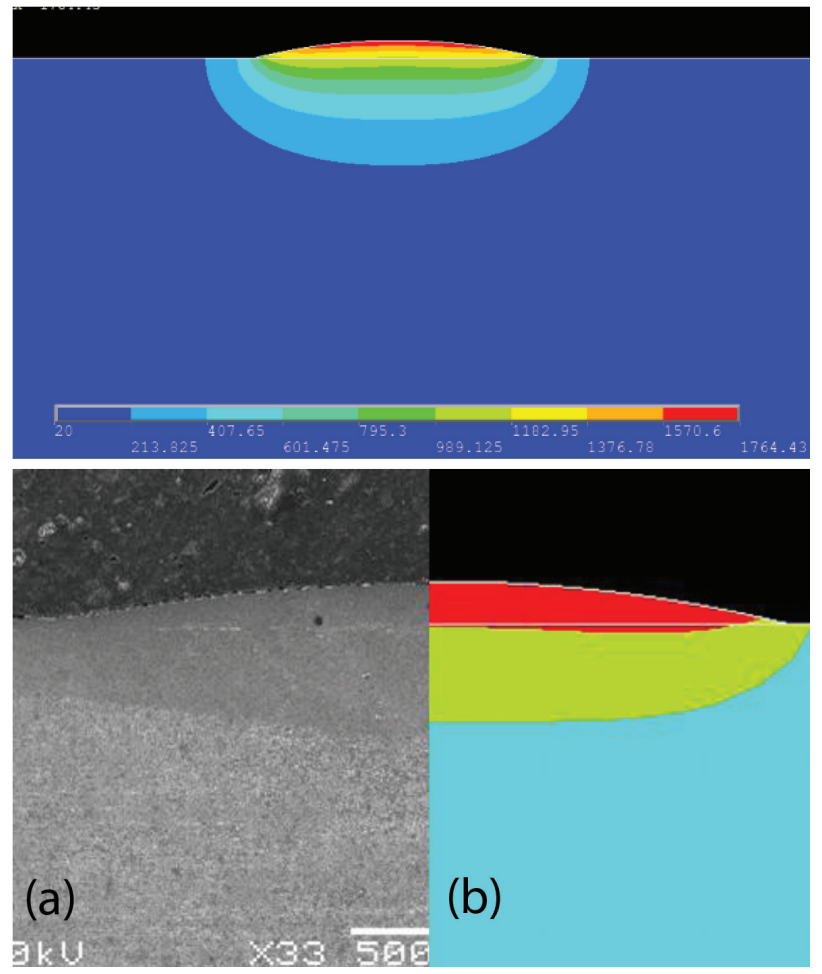

Figure 6: a) Cross-sectional temperature distribution and b) its comparison with the experimental results 
the temperature predicted by the developed model is in good agreement with the simulated results. The simulated results can be used to analyze the thermal cycle during the laser-cladding process.

The temperature variation at a fixed point during the full laser-cladding time for all the coatings was derived from the FE simulation results and depicted in Figure 7. In detail, the fixed point is in the center symmetry plane and on the top surface of the coating. All the curves illustrate that the temperatures changed remarkably; they were the first to increase in the heating process and then they decreased in the cooling process. Figure 7 also shows that the peak temperature of each coating was different; the peak temperature was at its maximum when the heat input was $131.1 \mathrm{~J} / \mathrm{mm}$ and then it decreased with the decrease in the heat inputs. In addition, it can be observed that the high-temperature duration also decreased with the decrease in the heat inputs. Meanwhile, it can be inferred that the duration of the molten pool was reduced.

For bulk metallic glasses, if a liquid is cooled below the melting point $\left(T_{\mathrm{m}}\right)$, the liquid enters into the region of $T_{\mathrm{m}}$ to $T_{\mathrm{g}}$ (glass transition temperature). In this study, the $T_{\mathrm{g}}$ of the Ni-based alloy is $743 \mathrm{~K}$. The free energy difference between the liquid and a crystal provides a driving force for crystal nucleation. If the cooling rate between $T_{\mathrm{m}}$ and $T_{\mathrm{g}}$ is very high, then high viscosity and sluggish kinetics in the supercooled liquid state are obtained; as a result, the liquid can be undercooled into the amorphous state. Therefore, when the nucleation is suppressed, the minimum cooling rate between the highest temperature and $T_{\mathrm{g}}$ is called the critical cooling rate $\left(R_{\mathrm{c}}\right)$. In this study, the temperature variation of the fixed node was used to study the entire trend of the thermal-field variation in the cladded coating. Therefore, the cooling rates from the highest temperature to $T_{\mathrm{g}}$ for different heat inputs were calculated in accordance with Figure 7 and depicted in Figure 8. As seen from Figure $\mathbf{8}$, with a decrease in the heat input, the cooling rate rises

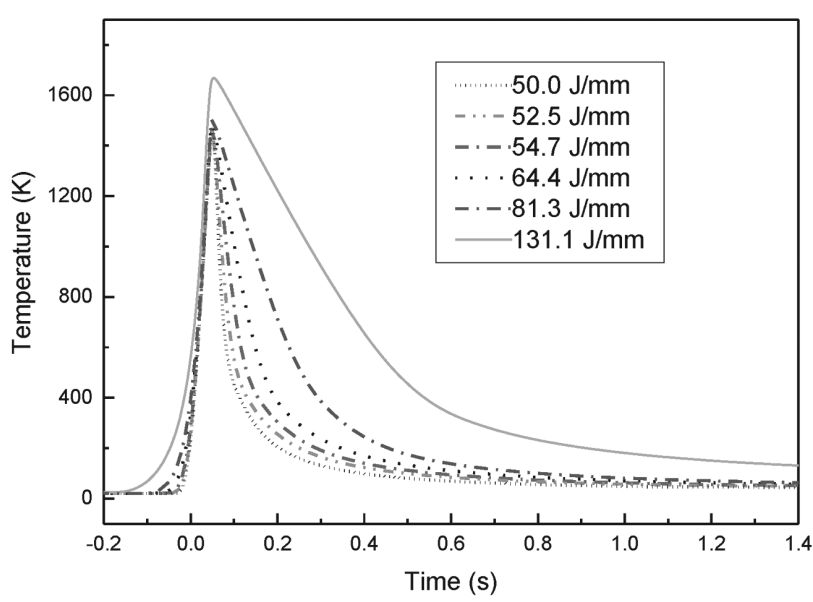

Figure 7: Thermal-cycle curves of the laser-cladded coating at different heat inputs

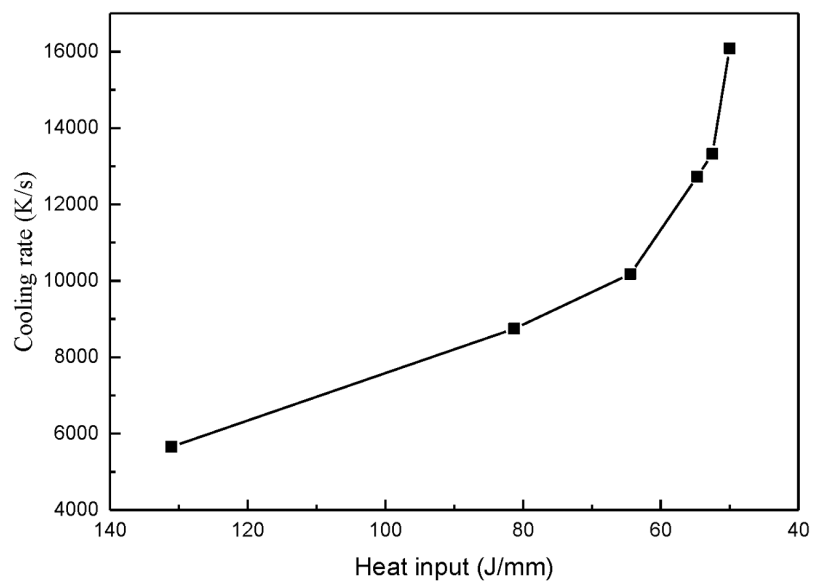

Figure 8: Effect of heat input on the cooling rate of the coatings

rapidly. The cooling rate reaches $16087 \mathrm{~K} / \mathrm{s}$ when the laser-cladding heat input is $50 \mathrm{~J} / \mathrm{mm}$. For the Ni-based alloy used in this study, a $R \mathrm{c}$ value of $49.3 \mathrm{~K} / \mathrm{s}$ was obtained based on the study of Z. P. Lu. ${ }^{20}$ It can be seen that the cooling rate for all the laser-cladding inputs is much higher than $R_{\mathrm{c}}$. However, the amorphous structure is not obtained at heat inputs of $131.3 \mathrm{~J} / \mathrm{mm}$ and 81.3 $\mathrm{J} / \mathrm{mm}$, for which the cooling rates are $5657 \mathrm{~K} / \mathrm{s}$ and 8744 $\mathrm{K} / \mathrm{s}$, respectively. The reason for this may be the fact that at high heat inputs, the composition of the coating is far away from the designed composition due to a large dilution rate. In addition, the lack of amorphous phase may also attribute to the heterogeneous nucleation during the laser-cladding process. ${ }^{21,22}$

\section{CONCLUSIONS}

In this study, a $\left(\mathrm{N}_{\mathrm{i} 0.6} \mathrm{Fe}_{0.4}\right)_{65} \mathrm{~B}_{18} \mathrm{Si}_{10} \mathrm{Nb}_{4} \mathrm{C}_{3}$ alloy powder was deposited onto low-carbon steel at different heat inputs using laser cladding. The microstructure of the coatings was investigated. The process of laser cladding was simulated using the FEM method. The temperature/ time behavior of the coating was obtained to analyze the amorphous formation during the laser-cladding process.

The microstructure of the coating was observed with the SEM, TEM and XRD methods. The coating consisted of both amorphous and crystalline phases; the fraction of the amorphous phase increased with a decrease in the laser-cladding heat inputs.

The simulation of laser cladding for the temperaturefield analysis was achieved using a 3D FE simulation. The instantaneous temperature distribution and temperature curves were obtained; the cooling rate of fixed nodes was calculated. It was validated with the experimental results, showing a high degree of agreement.

The simulation results indicated that a decrease in the heat input leads to a higher cooling rate. Hence, the heat input has a strong correlation with the amorphous-forming ability during laser cladding. 


\section{Acknowledgements}

The authors would like to acknowledge the financial support provided by the National Key Research and Development Program of China (no. 2018YFC0310400), the National Natural Science Foundation of China (Grant nos. 51775254 \& 51405206) and the China Postdoctoral Science Foundation (Grant no. 2017M611750).

\section{REFERENCES}

${ }^{1}$ I. Smurov, Laser cladding and laser assisted direct manufacturing, Surf. Coat. Technol., 202 (2008), 4496-4502, doi:10.1016/j.surfcoat. 2008.04.033

${ }^{2}$ B. Liu, S. Dong, Anisotropic structure affects thickness measurement of laser cladding coating with surface ultrasonic wave based on cross-correlation function, Mater. Res. Innovations, 19 (2015), 194-198, doi:10.1179/1432891714Z.0000000001076

${ }^{3}$ S. S. Joshi, S. Katakam, H. S. Arora, Amorphous coatings and surfaces on structural materials, Crit. Rev. Solid State Mater. Sci., 41 (2015), 1-46, doi:10.1080/10408436.2015.1053602

${ }^{4}$ X. Y. Ye, Y. C. Shin, Synthesis and characterization of Fe-based amorphous composite by laser direct deposition, Surf. Coat. Technol., 239 (2014), 34-40, doi:10.1016/j.surfcoat.2013.11.013

${ }^{5}$ Y. Zhu, Z. Li, R. Li, High power diode laser cladding of $\mathrm{Fe}-\mathrm{Co}-$ $\mathrm{B}-\mathrm{Si}-\mathrm{C}-\mathrm{Nb}$ amorphous coating: Layered microstructure and properties, Surf. Coat. Technol., 235 (2013), 699-705, doi:10.1016/j.surfcoat.2013.08.050

${ }^{6} \mathrm{P}$. L. Zhang, H. Yan, Synthesis of $\mathrm{Fe}-\mathrm{Ni}-\mathrm{B}-\mathrm{Si}-\mathrm{Nb}$ amorphous and crystalline composite coatings by laser cladding and remelting, Surf. Coat. Technol., 206 (2011), 1229-1236, doi:10.1016/j.surfcoat.2011. 08.039

${ }^{7}$ G. L. Yang, X. Lin, F. C. Liu, Q. Hu, Laser solid forming Zr-based bulk metallic glass, Intermetallics, 22 (2012), 110-115, doi:10.1016/ j.intermet.2011.10.008

${ }^{8}$ T. M. Yue, Y. P. Su, Laser multi-layer cladding of Zr65A17.5Ni10Cu17.5 amorphous alloy on magnesium substrates, J. Mater. Sci., 42 (2007), 6153-6160, doi:10.1007/s10853-006-1134-0

${ }^{9}$ M. Aghasibeig, H. Fredriksson, Laser cladding of a featureless ironbased alloy, Surf. Coat. Technol., 209 (2012), 32-37, doi:10.1016/ j.surfcoat.2012.08.013

${ }^{10}$ Y. Z. Lu, G. K. Huang, Y. Z. Wang, H. G. Li, Z. X. Qin, X. Lu, Crack-free Fe-based amorphous coating synthesized by laser cladding, Mater. Lett., 210 (2018), 46-50, doi:10.1016/j.matlet. 2017.08.125

${ }^{11}$ S. F. Zhou, Y. B. Xu, B. Q. Liao, Y. J. Sun, X. Q. Dai, J. X. Yang, Z. Y. Li, Effect of laser remelting on microstructure and properties of
WC reinforced Fe-based amorphous composite coatings by laser cladding, Opt. Laser Technol., 103 (2018), 8-16, doi:10.1016/ j.optlastec.2018.01.024

${ }^{12}$ A. Inoue, A. Takeuchi, Recent development and application products of bulk glassy alloys, Acta Mater., 59 (2011), 2243-2267, doi:10.1016/j.actamat.2010.11.027

${ }^{13}$ M. Doubenskaia, M. Pavlov, S. Grigoriev, Definition of brightness temperature and restoration of true temperature in laser cladding using infrared camera, Surf. Coat. Technol., 220 (2013), 244-247, doi:10.1016/j.surfcoat.2012.10.044

${ }^{14}$ P. Farahmand, R. Kovacevic, An experimental-numerical investigation of heat distribution and stress field in single- and multi-track laser cladding by a high-power direct diode laser, Opt. Laser Technol., 63 (2014), 154-168, doi:10.1016/j.optlastec.2014.04.016

${ }^{15}$ M. Z. Hao, Y. W. Sun, A FEM model for simulating temperature field in coaxial laser cladding of TI6AL4V alloy using an inverse modeling approach, Int. J. Heat Mass Transfer, 64 (2013), 352-360, doi:10.1016/j.ijheatmasstransfer.2013.04.050

${ }^{16}$ H. W. Yang, J. Wen, M. X. Quan, J. Q. Wang, Evaluation of the volume fraction of nanocrystals devitrified in Al-based amorphous alloys, J. Non-Cryst. Solids, 355 (2009), 235-238, doi:10.1016/ j.jnoncrysol.2008.12.001

${ }^{17}$ R. Li, Y. Jin, Z. Li, Y. Zhu, M. Wu, Effect of the remelting scanning speed on the amorphous forming ability of Ni-based alloy using laser cladding plus a laser remelting process, Surf. Coat. Technol., 259 (2014), 725-731, doi:10.1016/j.surfcoat.2014.09.067

${ }^{18}$ C. Liu, J. W. Yang, Y. F. Shi, Q. Fu, Y. Zhao, Modelling of residual stresses in a narrow-gap welding of ultra-thick curved steel mockup, J. Mater. Process. Technol., 256 (2018), 239-246, doi:10.1016/ j.jmatprotec.2018.02.024

${ }^{19}$ G. X. Xu, J. Y. Wang, P. F. Li, J. Zhu, Q. N. Cao, Numerical analysis of heat transfer and fluid flow in swing arc narrow gap GMA welding, J. Mater. Process. Technol., 252 (2018), 260-269, doi:10.1016/ j.jmatprotec.2017.09.030

${ }^{20}$ Z. P. Lu, C. T. Liu, A new glass-forming ability criterion for bulk metallic glasses, Acta Mater., 50 (2002), 3501-3512, doi:10.1016/ s1359-6454(02)00166-0

${ }^{21}$ P. Gargarella, A. Almeida, R. Vilar, C. R. M. Afonso, S. Peripolli, C. T. Rios, C. Bolfarini, W. J. Botta, C. S. Kiminami, Formation of Fe-based glassy matrix composite coatings by laser processing, Surf. Coat. Technol., 240 (2014), 336-343, doi:10.1016/j.surfcoat.2013. 12.049

${ }^{22}$ S. Chen, R. Li, Q. Zheng, Z. Li, Layered microstructure distribution and forming mechanism of laser-processed Ni-Fe-B-Si-Nb-C amorphous composite coatings, Mater. Trans., 57 (2016), 1807-1810, doi:10.2320/matertrans.m2016189 